Check for updates

Cite this: RSC Adv., 2019, 9, 12675

Received 13th February 2019

Accepted 8th April 2019

DOI: 10.1039/c9ra01122f

rsc.li/rsc-advances

\title{
A fluorescent and colorimetric probe based on naphthalene diimide and its high sensitivity towards copper ions when used as test strips $\dagger$
}

\author{
Luyi Zong, ${ }^{\text {ab }}$ Can Wang, ${ }^{a}$ Yuchen Song, ${ }^{a}$ Jie Hu, ${ }^{a}$ Qianqian Li (iD *a and Zhen Li ${ }^{* a}$ \\ Herein, a red fluorescent and colorimetric probe (NDI-Py) based on naphthalene diimide was \\ designed and synthesized, which exhibited rapid response, high sensitivity and selectivity towards \\ copper ions, and the detection limit was as low as $0.97 \mu \mathrm{M}$ in solution. Furthermore, NDI-Py \\ demonstrated a strong red emission in the aggregated state because of its non-planar structure. \\ Thus, it can act as a test strip to conveniently monitor copper ions with the detection limit as low \\ as $2.0 \mu \mathrm{M}$.
}

\section{Introduction}

In the past few decades, extensive attention has been devoted to the detection of heavy metal ions due to their important biological and ecological relevance. ${ }^{1}$ For instance, overloading of copper ions in the human body can induce many serious diseases such as Parkinson's and prion diseases, ${ }^{2}$ Alzheimer's disease, ${ }^{3}$ and liver and kidney damage; ${ }^{4}$ according to the U.S. Environmental Protection Agency (EPA), the upper limit of copper ions in drinking water is $1.3 \mathrm{ppm}$ (about $20 \mu \mathrm{M}$ ); thus, the development of copper-selective probes with high sensitivity is of great importance. To date, various probes have been constructed based on different conjugated systems, such as coumarin, ${ }^{5}$ 1,8-naphthalimide, ${ }^{6}$ fluorescein, ${ }^{7}$ perylene ${ }^{8}$ and rhodamine derivatives ${ }^{9}$ and others, ${ }^{10}$ which are mainly related to fluorescence or colorimetric detection. ${ }^{11}$ Normally, colorimetric detection can be achieved by naked eyes, which has been proven to be more convenient and easier; on the other hand, fluorescent probes usually exhibit higher sensitivity due to fluorescence emission; ${ }^{12}$ thus, the combination of these two detection methods should be an excellent choice to realize more efficient monitoring of metal ions.

Accordingly, to realize the dual functional detection of copper ions (Chart 1), a strong electron pull-push system (NDI-Py) was constructed, in which naphthalene diimide (NDI) with a typical electron-deficient structure acted as an electron

${ }^{a}$ Department of Chemistry, Wuhan University, Wuhan 430072, China. E-mail: qianqian-alinda@163.com; lizhen@whu.edu.cn; Fax: +86-27-68755363; Tel: +86-2768755363

${ }^{b}$ College of Chemistry and Pharmaceutical Engineering, Nanyang Normal University, Nanyang, 473061, P. R. China

$\dagger$ Electronic supplementary information (ESI) available: The UV-visible, fluorescence spectra, the job's plot and the characteristic of the structure of NDI-Py. See DOI: 10.1039/c9ra01122f acceptor $^{\mathbf{1 3}}$ and 2-methylamino pyridine (Py) was employed as an electron donor and a receptor towards copper ions. The conjugation mode of these two moieties resulted in a strong intramolecular charge transfer (ICT) through the entire molecule; accordingly, the incorporation of an ester unit and an ether linkage into $R_{1}$ was conducted to improve the solubility of the probe in water, and the branched unit in $\mathrm{R}_{2}$ could suppress the $\pi-\pi$ stacking by steric hindrance, which was beneficial for the application of the proposed probe as an aggregated molecule. The resultant probe NDI-Py exhibited a strong red fluorescence with the maximum emission wavelength of $638 \mathrm{~nm}$. This deep-red emission can be favourable for the possible applications of this probe in bioimaging. Upon the addition of trace copper ions, the fluorescence rapidly disappeared mainly due to the inherent paramagnetism of $\mathrm{Cu}^{2+}$, and the absorption spectrum red-shifted by about $60 \mathrm{~nm}$ with an obvious color change of solution from blue-purple to bluish-green. Furthermore, the probe NDI-Py could be applied into the silica gel plates to achieve the more convenient monitoring, and the detection limit was as low as $2.0 \mu \mathrm{M}$.

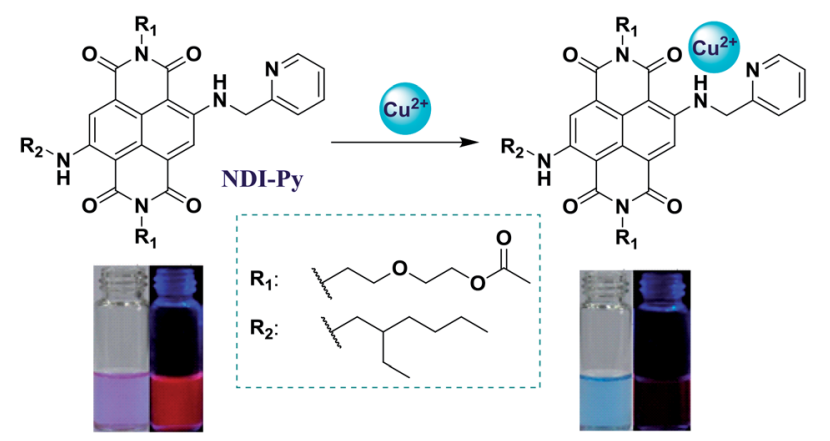

Chart 1 The fluorescent and colorimetric responses of NDI-Py towards copper ions. 


\section{Results and discussion}

\section{Response of NDI-Py towards $\mathrm{Cu}^{2+}$}

With the aim to investigate the optical properties of NDI-Py and its response towards copper ions, the absorption and fluorescence spectra of NDI-Py in the absence and presence of copper ions were obtained. As shown in Fig. 1, the solution of the probe NDI-Py in acetone $(10 \mu \mathrm{M})$ exhibited lavender color with the maximum absorption wavelength at $603 \mathrm{~nm}$. A strong red fluorescence could be observed with the maximum emission wavelength of $638 \mathrm{~nm}$. Upon the addition of copper ions, the absorption spectrum red-shifted by about $60 \mathrm{~nm}$ along with a change in the solution color to bluish-green (Fig. 1A, inset). This indicated that NDI-Py could serve as a naked-eye indicator towards copper ions. Moreover, the fluorescence intensity of NDI-Py was quenched significantly (about 64-fold) and quickly (about 30 seconds) by the copper ions in trace amounts (Fig. 1B and S1 $)$ ). These results suggested that NDIPy could serve as a real-time colorimetric and fluorescent probe.

\section{Selectivity of NDI-Py towards copper ions}

High selectivity of a probe for copper ions over other competing metal ions is of great significance for the practical applications of the probe, especially in biological systems and complex environmental sources. Thus, the selectivity of NDI-Py towards copper ions in the presence of various metal ions was examined by UV-visible absorption and fluorescence spectra. As shown in Fig. $2 \mathrm{~A}$ and $\mathrm{S} 3, \uparrow$ the copper ions could induce a red-shift in the absorption spectrum, whereas other metal ions, such as $\mathrm{Li}^{+}$, $\mathrm{Ba}^{2+}, \mathrm{Co}^{2+}, \mathrm{Fe}^{2+}, \mathrm{Zn}^{2+}, \mathrm{Mg}^{2+}, \mathrm{Na}^{+}, \mathrm{Ca}^{2+}, \mathrm{K}^{+}, \mathrm{Pb}^{2+}, \mathrm{Cd}^{2+}, \mathrm{Cr}^{3+}, \mathrm{Al}^{3+}$, $\mathrm{Ag}^{+}, \mathrm{Mn}^{2+}$ and $\mathrm{Fe}^{3+}$, showed almost no obvious interference. Although $\mathrm{Hg}^{2+}$ could induce a slight blue shift $(16 \mathrm{~nm})$ in the absorption spectrum, it still showed a negligible effect on the detection of $\mathrm{Cu}^{2+}$. The corresponding fluorescence responses are shown in Fig. 2B. After the addition of copper ions, a dramatic fluorescence quenching of about 64-fold was immediately observed. Nearly no obvious change in the fluorescence spectra was noted in the presence of other metal ions.
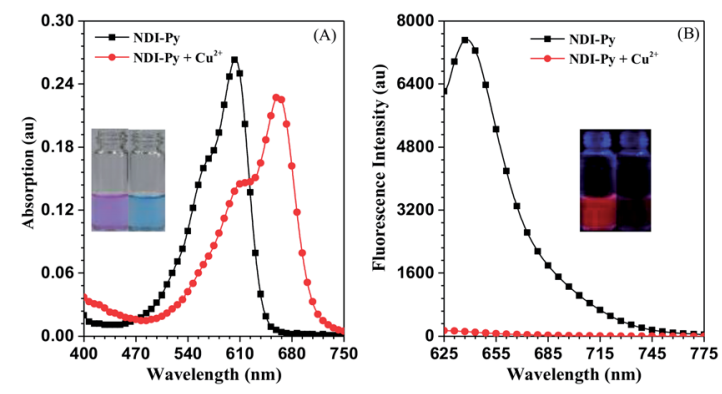

Fig. 1 (A) The UV-visible spectra of NDI-Py in acetone $(20 \mu \mathrm{M})$ in the absence and presence of 1.0 equiv. of copper ions. Inset: images of $\mathrm{NDI}-\mathrm{Py}$ in the absence and presence of $\mathrm{Cu}^{2+} ;(\mathrm{B})$ the fluorescence spectra of NDI-Py in acetone $(10 \mu \mathrm{M})$ in the absence and presence of 1.0 equiv. of copper ions. Inset: the fluorescence images of NDI-Py in the absence and presence of $\mathrm{Cu}^{2+}$.
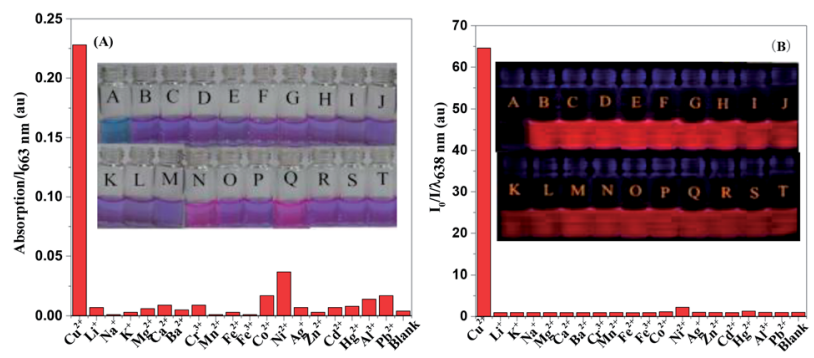

Fig. 2 (A) The changes in the absorption of NDI-Py in acetone $(20 \mu \mathrm{M})$ at $663 \mathrm{~nm}$ towards 1.0 equiv. of various metal ions. Inset: the images of NDI-Py with various metal ions: (A) $\mathrm{Cu}^{2+},(B) \mathrm{Li}^{+},(\mathrm{C}) \mathrm{Na}^{+},(\mathrm{D}) \mathrm{K}^{+},(\mathrm{E})$ $\mathrm{Mg}^{2+}$, (F) $\mathrm{Ca}^{2+}$, (G) $\mathrm{Ba}^{2+},(\mathrm{H}) \mathrm{Cr}^{3+}$, (I) $\mathrm{Mn}^{2+}$, (J) $\mathrm{Fe}^{2+}$, (K) $\mathrm{Fe}^{3+}$, (L) $\mathrm{Co}^{2+}$, (M) $\mathrm{Ni}^{2+},(\mathrm{N}) \mathrm{Ag}^{+},(\mathrm{O}) \mathrm{Zn}^{2+}$, (P) $\mathrm{Cd}^{2+},(\mathrm{Q}) \mathrm{Hg}^{2+}$, (R) $\mathrm{Al}^{3+},(\mathrm{S}) \mathrm{Pb}^{2+}$, and (T) blank; (B) the profiles of fluorescence spectra of NDI-Py in acetone (10 $\mu \mathrm{M})$ towards 1.0 equiv. of various metal ions. Inset: fluorescence images of NDI-Py with various metal ions under a UV lamp: (A) $\mathrm{Cu}^{2+}$, (B) $\mathrm{Li}^{+}$, (C) $\mathrm{Na}^{+}$, (D) $\mathrm{K}^{+}$, (E) $\mathrm{Mg}^{2+}$, (F) $\mathrm{Ca}^{2+}$, (G) $\mathrm{Ba}^{2+}$, (H) $\mathrm{Cr}^{3+}$, (I) $\mathrm{Mn}^{2+}$, (J) $\mathrm{Fe}^{2+},(\mathrm{K}) \mathrm{Fe}^{3+},(\mathrm{L}) \mathrm{Co}^{2+},(\mathrm{M}) \mathrm{Ni}^{2+},(\mathrm{N}) \mathrm{Ag}^{+},(\mathrm{O}) \mathrm{Zn}^{2+},(\mathrm{P}) \mathrm{Cd}^{2+},(\mathrm{Q}) \mathrm{Hg}^{2+}$, (R) $\mathrm{Al}^{3+},(\mathrm{S}) \mathrm{Pb}^{2+}$, and (T) blank.

In addition, the effect of various involved anions has been investigated (Fig. S4†), and nearly no fluorescence change can be observed upon the addition of sulfate, nitrate and hydrochloride. These results obtained by colorimetric and fluorescence detection demonstrated that NDI-Py exhibited high selectivity towards copper ions.

The anti-interference ability is also an important factor for real applications. Contrast experiments in the presence of competing metal ions were conducted (Fig. 3). Copper ions could induce similar color and fluorescence changes in the presence of other competing metal ions as those caused by copper only. That is, other metal ions did not interfere with the detection of copper ions under competitive conditions. Furthermore, the fluorescence response of NDI-Py towards copper ions with the simultaneous existence of competing metal ions was investigated (Fig. S5†); upon the addition of
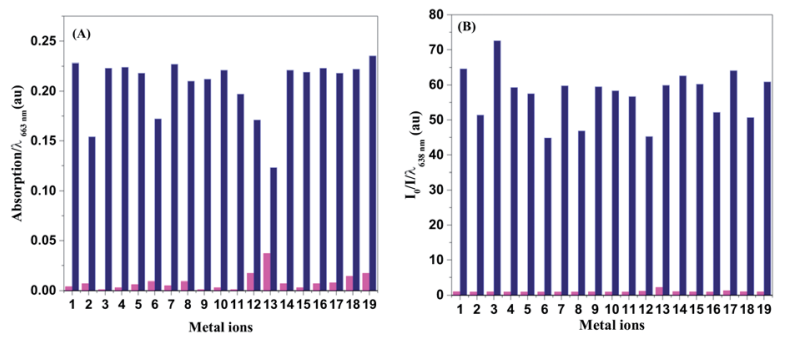

Fig. 3 (A) The profiles of the UV-visible spectra of NDI-Py $(20 \mu \mathrm{M})$ towards copper ions (1.0 equiv.) in the presence of other competing metal ions (1.0 equiv.); (B) the changes in the fluorescence intensity of NDI-Py $(10 \mu \mathrm{M})$ towards copper ions (1.0 equiv.) in the presence of other competing metal ions (1.0 equiv.) (1) blank, (2) $\mathrm{Li}^{+}$, (3) $\mathrm{Na}^{+}$, (4) $\mathrm{K}^{+}$, (5) $\mathrm{Mg}^{2+},(6) \mathrm{Ca}^{2+}$, (7) $\mathrm{Ba}^{2+}$, (8) $\mathrm{Cr}^{3+}$, (9) $\mathrm{Mn}^{2+}$, (10) $\mathrm{Fe}^{2+}$, (11) $\mathrm{Fe}^{3+}$, (12) $\mathrm{Co}^{2+}$, (13) $\mathrm{Ni}^{2+}$, (14) $\mathrm{Ag}^{+}$, (15) $\mathrm{Zn}^{2+}$, (16) $\mathrm{Cd}^{+}$, (17) $\mathrm{Hg}^{2+}$, (18) $\mathrm{Al}^{3+}$, and (19) $\mathrm{Pb}^{2+}$. The magenta bars represent the data obtained upon the addition of various metal ions, and the navy bars represent the data obtained upon the addition of copper ions in the presence of other competing metal ions. 
various metals ions except for copper ions, the fluorescence intensity of NDI-Py exhibited a negligible change. When the copper ions were introduced, the fluorescence was significantly quenched even when the competing metal ions existed at the same time. These results further confirmed that NDI-Py could monitor copper ions with high selectivity in practical applications. Moreover, the sensing behavior of NDI-Py in an aqueous solution was investigated, and $N$-2-hydroxyethylpiperazine- $N^{\prime}-2$ ethanesulfonic acid (HEPES) was chosen as a buffer in the neutral $\mathrm{pH}$ range. Since the addition of water could cause quenching of the fluorescence emission and red-shift of the fluorescence spectra (Fig. S6†) due to the larger polarity of water, an acetone: HEPES solution at the ratio of $7: 3$ was chosen as a suitable solvent system. Similarly, only copper ions could reduce the fluorescent intensity of NDI-Py by about 8-fold, whereas other metal ions had a negligible effect (Fig. S7 $\dagger$ ), and the high selectivity could also be proved by competitive experiments (Fig. S8†).

\section{Sensitivity of NDI-Py towards copper ions}

The titration curve towards copper ions is shown in Fig. 4. At first, the absorption peak of NDI-Py in solution was located at $603 \mathrm{~nm}$. With an increase in the amount of copper ions, absorption at $603 \mathrm{~nm}$ decreased gradually with the appearance of a new band at $663 \mathrm{~nm}$ (Fig. S9†). It was mainly attributed to the deprotonation of the N-H group in NDI-Py by copper ions, which could strengthen the ICT effect through the entire molecule. A similar phenomenon has also been reported in the literature. ${ }^{14}$ The absorption at $663 \mathrm{~nm}$ reached maximum when the concentration of copper ions was the same as that of NDI-Py; this suggested a $1: 1$ coordination in the complex NDI-Py-Cu $\mathbf{C u}^{2+}$. This was further confirmed by the Job's plot (Fig. S10 ${ }^{\dagger}$ ) and the ESI-MS spectrum (Fig. S11†). In the fluorescence spectra, the strong red fluorescence of NDI-Py with the peak at $638 \mathrm{~nm}$ could be decreased gradually with the dropwise addition of copper ions; this was mainly caused by the inherent paramagnetism of cooper ions, as reported in many studies. ${ }^{15}$ The detection limit of NDI-Py towards copper ions was calculated to be $7.1 \mu \mathrm{M}$, and it could be further improved to $0.96 \mu \mathrm{M}$ by decreasing the concentration of the NDI-Py solution to $2.0 \mu \mathrm{M}$ (Fig. S12 and $\mathrm{S} 13 \dagger)$; this indicated high sensitivity of the probe towards
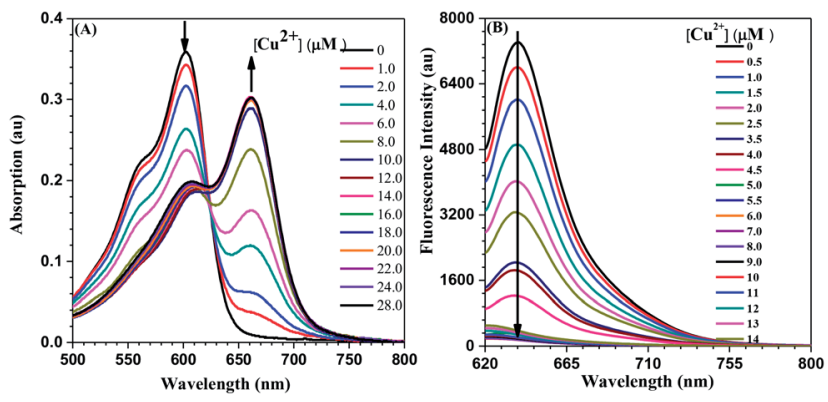

Fig. 4 (A) The UV-visible spectra of NDI-Py $(20 \mu \mathrm{M})$ in acetone with $\mathrm{Cu}^{2+}$ at different concentrations; (B) the fluorescence spectra of NDIPy $(10 \mu \mathrm{M})$ in acetone with $\mathrm{Cu}^{2+}$ at different concentrations. copper ions. Note that this is much lower than the standard level of copper ions in the drinking water $(20 \mu \mathrm{M})$ permitted by the U.S. EPA.

\section{Effect of pH on the fluorescence response of NDI-Py}

To obtain insights into the influence of various $\mathrm{pH}$ values on the probe function, the fluorescence behaviors of NDI-Py and NDI-Py-Cu $\mathbf{u}^{2+}$ under acidic or basic conditions were studied. The fluorescence intensity of NDI-Py showed negligible changes when the $\mathrm{pH}$ values varied from 1.03 to 12.77 (Fig. S14 $\dagger$ ). Upon the addition of copper ions, the corresponding fluorescence intensities of NDI-Py-C $\mathbf{u}^{2+}$ decreased sharply when the $\mathrm{pH}$ values increased from 1.0 to 4.0 and remained stable at $\mathrm{pH}$ values ranging from 4.0 to 8.0. These results demonstrate that NDI-Py can monitor $\mathrm{Cu}^{2+}$ in a wide $\mathrm{pH}$ range and is suitable for practical applications under biological conditions.

\section{The sensing behavior of NDI-Py in silica gel plates}

In addition to the high sensitivity and selectivity of NDI-Py towards copper ions, it presented excellent photostability, as proved by the negligible fluorescence change under continuous irradiation (Fig. S2 $\dagger$ ). These excellent performances inspired us to further investigate the possible application of NDI-Py as test strips. Silica gel plates are a good molecular carrier, which exhibit non-toxicity, tastelessness, strong elasticity, and high thermal stability. After being immersed in the solution of NDIPy $\left(2.0 \times 10^{-4} \mathrm{~mol} \mathrm{~L}^{-1}\right)$ for 20 minutes and dried in air, the test strips were obtained by physical absorption. When they were exposed to UV light (365 nm), a strong red fluorescence in the aggregated state could be observed, revealing that the common aggregation-caused quenching (ACQ) effect as in many NDIbased molecules has been inhibited in NDI-Py. ${ }^{\mathbf{1 6}}$ It is mainly due to the non-planar structure of NDI-Py, which can suppress the strong $\pi-\pi$ stacking in the aggregated state. Then, solutions of copper ions with different concentrations were placed on the silica gel plates to form the word "NDI". As shown in Fig. 5, with the increasing concentration of copper ions, dose-dependent turn-off progress of fluorescence was observed. Even when the concentration of copper ions was only $2.0 \mu \mathrm{M}$, the quenching effect could be recognized; when it further increased to $100 \mu \mathrm{M}$, the fluorescence was completely quenched; this proved that NDI-Py could detect copper ions in the test strips with high sensitivity.

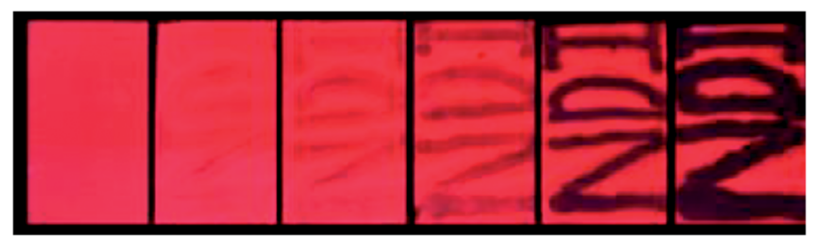

Fig. 5 Images of silica gel plates with copper ions ("NDI" pattern) at different concentrations under a UV-lamp. From left to right, the concentrations of copper ions were $0,2.0 \times 10^{-6}, 2.0 \times 10^{-5}, 1.0 \times$ $10^{-4}, 1.0 \times 10^{-3}$, and $1.0 \times 10^{-2} \mathrm{~mol} \mathrm{~L}^{-1}$. 


\section{Conclusions}

In summary, we successfully synthesized a colorimetric and fluorescent probe, NDI-Py, based on naphthalene diimide for the fast detection of copper ions. The strong red fluorescence of NDI-Py could be sharply quenched by copper ions selectively with the detection limit as low as $0.97 \mu \mathrm{M}$ along with the change of solution from blue-purple to bluish-green. Furthermore, it could be applied to silica gel plates to achieve a more convenient analysis for real samples.

\section{Experimental}

\section{Materials and instrumentation}

All the chemicals were used without further purification. Compound 1 was synthesized according to a method described in the literature. ${ }^{17}$ Tetrahydrofuran (THF) was dried over and distilled from the K-Na alloy under an atmosphere of dry argon. ${ }^{1} \mathrm{H}$ and ${ }^{13} \mathrm{C}$ NMR spectroscopy were conducted using the Varian Mercury 300 spectrometer, in which tetramethylsilane (TMS; $\delta=0 \mathrm{ppm}$ ) served as the internal standard. The ultravioletvisible (UV-visible) spectra were obtained using the Shimadzu UV-2550 spectrometer. The fluorescence spectra were acquired using the Hitachi F-4600 fluorescence spectrophotometer. The mass spectrum was obtained by Thermo DSQ II. Elemental analysis was performed by the CARLOERBA-1106 microelemental analyzer. ESI determination was carried out using the Finnigan LCQ advantage mass spectrometer. The HR-MS spectrum was obtained using the GCT premier CAB048 mass spectrometer (Scheme 1).

\section{Synthesis of compound 2}

Compound 1 ( $2.30 \mathrm{~g}, 5.3 \mathrm{mmol})$ was mixed with glacial acetic acid $(80 \mathrm{~mL})$ in a flask, and 2-(2-aminoethoxy)ethanol $(2 \mathrm{~mL})$ was added under stirring; the mixture was stirred at $130{ }^{\circ} \mathrm{C}$ for 6 hours under a nitrogen atmosphere; after cooling the abovementioned solution down to room temperature, a red solid was obtained by filtration under reduced pressure. At last, the red solid was further purified by column chromatography to obtain compound 2 as a slight-yellow solid (500 mg, 13.8\%) with dichloromethane/acetone (40:1) as the eluent. ${ }^{1} \mathrm{H}$ NMR (300 $\left.\mathrm{MHz}, \mathrm{CDCl}_{3}, 25^{\circ} \mathrm{C}\right) \delta(\mathrm{ppm}): 9.00(\mathrm{~s}, 2 \mathrm{H}, \mathrm{ArH}), 4.48(\mathrm{t}, J=5.1 \mathrm{~Hz}$, $\left.4 \mathrm{H},-\mathrm{O}-\mathrm{CH}_{2}-\right), 4.19\left(\mathrm{t}, J=4.5 \mathrm{~Hz}, 4 \mathrm{H},-\mathrm{O}-\mathrm{CH}_{2}-\right), 3.87(\mathrm{t}, J=$ $\left.5.4 \mathrm{~Hz}, 4 \mathrm{H},-\mathrm{O}-\mathrm{CH}_{2}-\right), 3.75\left(\mathrm{t}, J=7.8 \mathrm{~Hz}, 4 \mathrm{H},-\mathrm{N}-\mathrm{CH}_{2}-\right), 2.00(\mathrm{~s}$, $\left.6 \mathrm{H},-\mathrm{CH}_{3}\right)$.

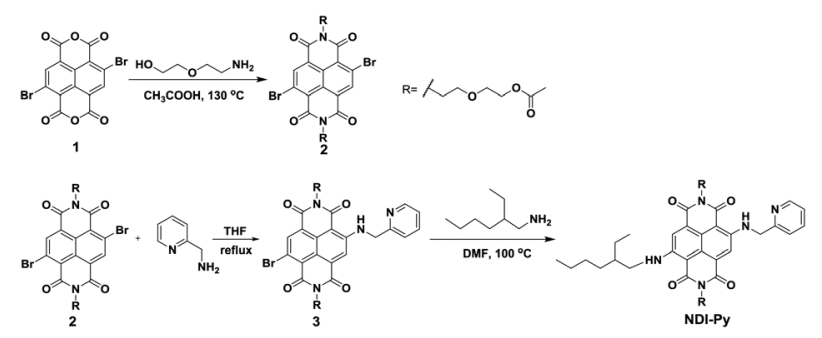

Scheme 1 The synthetic routes of NDI-Py.

\section{Synthesis of compound 3}

After compound $2(0.27 \mathrm{~g}, 0.40 \mathrm{mmol})$ was dissolved in anhydrous THF $(15 \mathrm{~mL})$ in a flask, 2-methylamino pyridine $(0.062$ $\mathrm{mL}, 0.60 \mathrm{mmol})$ and $\mathrm{K}_{2} \mathrm{CO}_{3}(607 \mathrm{mg}, 0.44 \mathrm{mmol})$ in anhydrous THF (15 mL) were added. The mixture was stirred at room temperature for $30 \mathrm{~min}$ and then refluxed for $6 \mathrm{~h}$ under a nitrogen atmosphere. THF was evaporated using a rotary evaporator, and a red solid was obtained. The crude product was further purified by column chromatography with dichloromethane/ethyl acetate $(5: 1)$ as the eluent to obtain compound 3 as a red solid (200 mg, 70.4\%). ${ }^{1} \mathrm{H}$ NMR $(300 \mathrm{MHz}$, $\left.\mathrm{CDCl}_{3}, 25^{\circ} \mathrm{C}\right) \delta(\mathrm{ppm}): 8.86(\mathrm{~s}, 1 \mathrm{H}, \mathrm{ArH}), 8.72$ (br, $\left.1 \mathrm{H}, \mathrm{ArH}\right), 8.32$ (s, 1H, ArH), $7.74(\mathrm{t}, J=6.0 \mathrm{~Hz}, 1 \mathrm{H}, \operatorname{ArH}), 7.38-7.26(\mathrm{~m}, 2 \mathrm{H}$, $\mathrm{ArH}), 4.94$ (br, $2 \mathrm{H},-\mathrm{N}-\mathrm{CH}_{2}-$ ), 4.50-4.42 (m, 4H,-O- $\left.\mathrm{CH}_{2}-\right)$, 4.19 (br, $4 \mathrm{H},-\mathrm{O}-\mathrm{CH}_{2}-$ ), $3.85\left(\mathrm{t}, J=5.7 \mathrm{~Hz}, 4 \mathrm{H},-\mathrm{O}-\mathrm{CH}_{2}-\right.$ ), 3.75 (br, $\left.4 \mathrm{H},-\mathrm{N}-\mathrm{CH}_{2}-\right), 2.00\left(\mathrm{~s}, 6 \mathrm{H},-\mathrm{CH}_{3}\right) .{ }^{13} \mathrm{C} \mathrm{NMR}\left(75 \mathrm{MHz}, \mathrm{CDCl}_{3}, 25\right.$ $\left.{ }^{\circ} \mathrm{C}\right) \delta(\mathrm{ppm}): 171.03,165.70,161.94,161.36,155.15,151.34$, 149.89, 138.32, 137.13, 128.55, 127.26, 123.49, 121.67, 120.74, $100.69,68.57,67.76,63.55,48.31,39.72,20.94$. MS (EI), $m / z\left[\mathrm{M}^{+}\right]$: calcd. 711.52 , found: 711.57 .

\section{Synthesis of the compound NDI-Py}

To compound 3 in DMF (15 mL) in a Schlenk tube (100 mL), 2ethylhexylamine $(0.4 \mathrm{~mL}, 0.30 \mathrm{mmol})$ was added dropwise. Then, the mixture was stirred at $100{ }^{\circ} \mathrm{C}$ for 4 hours under a nitrogen atmosphere. After being cooled down to room temperature, the resultant mixture was poured into water (100 $\mathrm{mL}$ ). The mixture was extracted several times with dichloromethane and dried with anhydrous $\mathrm{Na}_{2} \mathrm{SO}_{4}$. After the solvent was removed by a rotary evaporator, the crude product was further purified by column chromatography with ethyl acetate/ petroleum ether (v/v, $2: 1)$ as the eluent to obtain NDI-Py as a blue solid (30 mg, 26.3\%). ${ }^{1} \mathrm{H}$ NMR $\left(300 \mathrm{MHz}, \mathrm{CDCl}_{3}, 25{ }^{\circ} \mathrm{C}\right)$ $\delta$ (ppm): 8.69 (s, 1H, ArH), 8.18 (d, $J=9.0 \mathrm{~Hz}, 2 \mathrm{H}, \operatorname{ArH}), 7.70$ (t, $J$ $=7.5 \mathrm{~Hz}, 1 \mathrm{H}, \operatorname{ArH}), 7.37-7.26(\mathrm{~m}, 2 \mathrm{H}, \operatorname{ArH}), 4.87(\mathrm{br}, 2 \mathrm{H},-N-$ $\left.\mathrm{CH}_{2}{ }^{-}\right), 4.46\left(\mathrm{t}, J=6.9 \mathrm{~Hz}, 4 \mathrm{H},-\mathrm{O}-\mathrm{CH}_{2}-\right), 4.19\left(\mathrm{br}, 4 \mathrm{H},-\mathrm{O}-\mathrm{CH}_{2}-\right)$, 3.86 (br, 4H, $-\mathrm{O}-\mathrm{CH}_{2}-$ ), 3.75 (br, $4 \mathrm{H},-\mathrm{N}-\mathrm{CH}_{2}-$ ), $2.00(\mathrm{~s}, 6 \mathrm{H}$, $\left.-\mathrm{CH}_{3}\right), 1.76$ (br, $\left.2 \mathrm{H},-\mathrm{CH}_{2}-\right) .{ }^{13} \mathrm{C} \mathrm{NMR}\left(75 \mathrm{MHz}, \mathrm{CDCl}_{3}, 25{ }^{\circ} \mathrm{C}\right.$ ) $\delta$ (ppm): 170.89, 165.77, 162.74, 156.23, 149.62, 149.32, 148.19, 136.82, 125.48, 125.22, 122.51, 121.54, 121.13, 120.71, 118.02, 102.33, 101.09, 68.39, 67.75, 63.54, 48.23, 46.06, 38.90, 31.13, 29.59, 28.77, 24.39, 22.92, 20.79, 13.99, 10.86. MS (EI), $m / z\left[\mathrm{M}^{+}\right]$: 759.35, found: 759.54. Anal. calcd. for $\mathrm{C}_{40} \mathrm{H}_{49} \mathrm{~N}_{5} \mathrm{O}_{10}$ : C 63.23, $\mathrm{H}$ 6.50, N 9.22, found: C 63.02, H 6.38, N 9.11. HRMS, $m / z[\mathrm{M}+1]^{+}$ calcd. 760.3552 , found: 760.3558 .

\section{Solution preparation and optical measurements}

NDI-Py $(3.0 \mathrm{mg}, 4.0 \mu \mathrm{mol})$ was dissolved in acetone $(10 \mathrm{~mL})$ to obtain a stock solution with the concentration of $4.0 \times$ $10^{-4} \mathrm{~mol} \mathrm{~L}^{-1}$, which could be diluted to desired concentrations with an appropriate solvent medium. The stock solutions of various metal ions were prepared by dissolving corresponding metal salts, such as $\mathrm{NaNO}_{3}, \mathrm{KNO}_{3}, \mathrm{LiCl}, \mathrm{Ba}\left(\mathrm{NO}_{3}\right)_{2}, \mathrm{AgNO}_{3}$, $\mathrm{Cr}\left(\mathrm{NO}_{3}\right)_{3} \cdot 9 \mathrm{H}_{2} \mathrm{O}, \quad \mathrm{CoCl}_{2} \cdot 6 \mathrm{H}_{2} \mathrm{O}, \quad \mathrm{Pb}\left(\mathrm{NO}_{3}\right)_{2}, \quad \mathrm{Ni}\left(\mathrm{NO}_{3}\right)_{2} \cdot 6 \mathrm{H}_{2} \mathrm{O}$, $\mathrm{Zn}\left(\mathrm{NO}_{3}\right)_{2} \cdot 6 \mathrm{H}_{2} \mathrm{O}, \quad \mathrm{Cu}\left(\mathrm{NO}_{3}\right)_{2} \cdot 3 \mathrm{H}_{2} \mathrm{O}, \quad \mathrm{Al}\left(\mathrm{NO}_{3}\right)_{3} \cdot 9 \mathrm{H}_{2} \mathrm{O}$, 
$\mathrm{Fe}\left(\mathrm{NO}_{3}\right)_{3} \cdot 9 \mathrm{H}_{2} \mathrm{O}, \mathrm{MnSO}_{4} \cdot 2 \mathrm{H}_{2} \mathrm{O}, \mathrm{Cd}\left(\mathrm{NO}_{3}\right)_{2} \cdot 4 \mathrm{H}_{2} \mathrm{O}, \mathrm{FeSO}_{4} \cdot 7 \mathrm{H}_{2} \mathrm{O}$, $\mathrm{MgSO}_{4}, \mathrm{CaCl}_{2}, \mathrm{NiCl}_{2} \cdot 6 \mathrm{H}_{2} \mathrm{O}$ and $\mathrm{Hg}\left(\mathrm{ClO}_{4}\right)_{2} \cdot 3 \mathrm{H}_{2} \mathrm{O}$, in deionized water. The absorption and fluorescence spectra were obtained after the corresponding solutions were shaken well and incubated for $1 \mathrm{~min}$. The excitation wavelength was $605 \mathrm{~nm}$, and the excitation and emission slits were $5 \mathrm{~nm}$ each. The fluorescence emission was observed from $620 \mathrm{~nm}$ to $800 \mathrm{~nm}$.

\section{Conflicts of interest}

The authors declare no competing financial interest.

\section{Acknowledgements}

We are grateful to the National Science Foundation of China (51673151) and the Fundamental Research Funds for the Central Universities (2042018kf0014) for providing the financial support.

\section{Notes and references}

1 (a) L. Li, B. Yu and T. You, Biosens. Bioelectron., 2015, 74, 263; (b) H. Cheng and Y. Qian, Sens. Actuators, B, 2015, 219, 57; (c) J. Ru, X. Mi, L. Guan, X. Tang, Z. Ju, G. Zhang, C. Wang and W. Liu, J. Mater. Chem. B, 2015, 3, 6205; (d) H. Chang, Y. Chang, N. Fan and J. A. Ho, ACS Appl. Mater. Interfaces, 2014, 6, 18824; (e) N. Kumari, N. Dey and S. Bhattacharya, $R S C$ Adv., 2014, 4, 4230; $(f)$ M. P. Algi, Z. Öztas and F. Algi, Chem. Commun., 2012, 48, 10219; $(g)$ J. Liu and Y. Lu, J. Am. Chem. Soc., 2003, 125, 6642; (h) A. Coskun and E. U. Akkaya, J. Am. Chem. Soc., 2006, 128, 14474; (i) H. Li, J. Fan and X. Peng, Chem. Soc. Rev., 2013, 42, 7943; (j) Q. He, E. W. Miller, A. P. Wong and C. J. Chang, J. Am. Chem. Soc., 2006, 128, 9316.

2 (a) D. R. Brown and H. Kozlowski, Dalton Trans., 2004, 1907; (b) G. L. Millhauser, Acc. Chem. Res., 2004, 37, 79; (c) E. Gaggelli, H. Kozlowski, D. Valensin and G. Valensin, Chem. Rev., 2006, 106, 1995.

3 K. C. Ko, J. Wu, H. J. Kim, P. S. Kwon, J. W. Kim, R. A. Bartsch, J. Y. Lee and J. S. Kim, Chem. Commun., 2011, 47, 3165-3167. 4 (a) M. Taki, S. Iyoshi, A. Ojida, I. Hamachi and Y. Yamamoto, J. Am. Chem. Soc., 2010, 132, 5938; (b) Y. H. Hung, A. I. Bush and R. A. Chern, J. Biol. Inorg Chem., 2010, 15, 61.

5 (a) S. N. K. Elmas, F. Ozen, K. Koran, I. Yilmaz, A. O. Gorgulu and S. Erdemir, J. Fluoresc., 2017, 27, 463; (b) O. GarcíaBeltrán, N. Mena, L. C. Friedrich, J. C. Netto-Ferreira, V. Vargas, F. H. Quina, M. T. Núñez and B. K. Cassels, Tetrahedron Lett., 2012, 53, 5280; (c) H. S. Jung, P. S. Kwon, J. W. Lee, J. I. Kim, C. S. Hong, J. W. Kim, S. Yan, J. Y. Lee, J. H. Lee, T. Joo and J. S. Kim, J. Am. Chem. Soc., 2009, 131, 2008.

6 (a) C. Liu, X. Jiao, S. He, L. Zhao and X. Zeng, Org. Biomol. Chem., 2017, 15, 3947; (b) Y. Fu, C. Fan, G. Liu and S. Pu, Sens. Actuators, B, 2017, 239, 295.

7 (a) K. Huang, Y. Yue, X. Jiao, C. Liu, Q. Wang, S. He, L. Zhao and X. Zeng, Dyes Pigm., 2017, 143, 379; (b) L. E. McQuade and S. J. Lippard, Inorg. Chem., 2010, 49, 7464; (c) Z. Fu,
L. Yan, X. Zhang, F. Zhu, X. Han, J. Fang, Y. Wang and Y. Peng, Org. Biomol. Chem., 2017, 15, 4115.

8 (a) S. Goswami, S. Chakraborty, S. Paul, S. Halder, S. Panja and S. K. Mukhopadhyay, Org. Biomol. Chem., 2014, 12, 3037; (b) Y. Wang, L. Zhang, G. Zhang, Y. Wu, S. Wu and L. Wang, Tetrahedron Lett., 2014, 55, 3218.

9 (a) Y. Mi, Z. Cao, Y. Chen, Q. Xie, Y. Xu, Y. Luo, J. Shi and J. Xiang, Analyst, 2013, 138, 5274; (b) J. Sun, H. Mei and F. Gao, Biosens. Bioelectron., 2017, 91, 70; (c) B. Zhang, Q. Diao, P. Ma, X. Liu, D. Song and X. Wang, Sens. Actuators, B, 2016, 225, 579; (d) L. Huang, F. Chen, P. Xi, G. Xie, Z. Li, Y. Shi, M. Xu, H. Liu, Z. Ma, D. Bai and Z. Zeng, Dyes Pigm., 2011, 90, 265.

10 (a) L. Zeng, E. W. Miller, A. Pralle, E. Y. Isacoff and C. J. Chang, J. Am. Chem. Soc., 2006, 128, 10; (b) K. M. K. Swamy, S.-K. Ko, S. K. Kwon, H. N. Lee, C. Mao, J.-M. Kim, K.-H. Lee, J. Kim, I. Shin and J. Yoon, Chem. Commun., 2008, 5915; (c) G. J. Park, G. R. You, Y. W. Choi and C. Kim, Sens. Actuators, B, 2016, 229, 257.

11 (a) X. Zhu, Y. Duan, P. Li, H. Fan, T. Han and X. Huang, Anal. Methods, 2019, 11, 642; (b) H. Ye, F. Ge, Y. Zhou, J. Liu and B. Zhao, Spectrochim. Acta, Part A, 2013, 112, 132; (c) Z. Zhang, Y. Liu and E. Wang, Dyes Pigm., 2019, 163, 533; (d) X. Meng, D. Cao, Z. Hua, X. Han, Z. Li, D. Liang and W. Ma, Tetrahedron Lett., 2018, 59, 4299; (e) M. Wang, D. Zhang, M. Li, M. Fan, Y. Ye and Y. Zhao, J. Fluoresc., 2013, 23, 417; $(f)$ B. Gu, L. Huang, Z. Xu, Z. Tan, M. Hu, Z. Yang, Y. Chen, C. Peng, W. Xiao, D. Yu and H. Li, Sens. Actuators, B, 2018, 273, 118.

12 (a) D. Zhu, Y. Luo, X. Yan, W. Xie, W. Cai and X. Zhong, RSC $A d v .$, 2016, 6, 87110; (b) X. Wang, X. Ma, Z. Yang, Z. Zhang, J. Wen, Z. Geng and Z. Wang, Chem. Commun., 2013, 49, 11263.

13 (a) Z. Yuan, Y. Ma, T. Geßner, M. Li, L. Chen, M. Eustachi, R. T. Weitz, C. Li and K. Müllen, Org. Lett., 2016, 18, 456; (b) Z. Zhao, Z. Wang, C. Ge, X. Zhang, X. Yang and X. Gao, Polym. Chem., 2016, 7, 573; (c) C. R. DeBlase, K. Hernández-Burgos, J. M. Rotter, D. J. Fortman, D. S. Abreu, R. A. Timm, I. C. N. Diógenes, L. T. Kubota, H. D. Abruña and W. R. Dichte, Angew. Chem., Int. Ed., 2015, 54, 13225; (d) B. Xiao, G. Ding, Z. Tan and E. Zhou, Polym. Chem., 2015, 6, 7594; (e) H. Kar, M. R. Molla and S. Ghosh, Chem. Commun., 2013, 49, 4220; (f) D. Asthana, J. Shukla, S. Dana, V. Rani, M. R. Ajayakumar, K. Rawat, K. Mandal, P. Yadav, S. Ghosh and P. Mukhopadhyay, Chem. Commun., 2015, 51, 15237; (g) M. A. Kobaisi, S. V. Bhosale, K. Latham, A. M. Raynor and S. V. Bhosale, Chem. Rev., 2016, 116, 11685; (h) L. Zong, Y. Song, Q. Li and Z. Li, Sens. Actuators, B, 2016, 226, 239; (i) L. Zong, Y. Xie, Q. Li and Z. Li, Sens. Actuators, B, 2017, 238, 735; (j) N. Li, L. Zong, Q. Li and Z. Li, Sens. Actuators, B, 2015, 207, 827.

14 (a) F. Doria, V. Amendola, V. Grande, G. Bergamaschi and M. Freccer, Sens. Actuators, B, 2015, 212, 137; (b) Z. Xu, X. Qian and J. Cui, Org. Lett., 2005, 7, 3029; (c) J. Wang, Y. Xie, Z. Wang and Q. Song, Sens. Actuators, B, 2014, 194, 149. 
15 (a) Q. Li, Y. Guo and S. Shao, Sens. Actuators, B, 2012, 171172, 872; (b) X. Wu, Z. Guo, Y. Wu, S. Zhu, T. D. James and W. Zhu, ACS Appl. Mater. Interfaces, 2013, 5, 12215; (c) J. H. Jang, S. Bhuniya, J. Kang, A. Yeom, K. S. Hong and J. S. Kim, Org. Lett., 2013, 15, 4702.

16 (a) Q. Zhao, S. Zhang, Y. Liu, J. Mei, S. Chen, P. Lu, A. Qin, Y. Ma, J. Sun and B. Tang, J. Mater. Chem., 2012, 22, 7387; (b) G. Zhang, Z. Chen, M. P. Aldred, Z. Hu, T. Chen, Z. Huang, X. Meng and M. Zhu, Chem. Commun., 2014, 50, 12058; (c) L. Zong, Y. Xie, C. Wang, J.-R. Li, Q. Li and Z. Li, Chem. Commun., 2016, 52, 11496.

17 Q. Li, M. Peng, H. Li, C. Zhong, L. Zhang, X. Cheng, X. Peng, Q. Wang, J. Qin and Z. Li, Org. Lett., 2012, 14, 2094. 